\title{
A SOURCE OF ERROR IN THE ABSORPTIO- METRIC DETERMINATION OF INORGANIC AND TOTAL PHOSPHORUS IN SEA WATER
}

\author{
By F. A. J. Armstrong \\ From the Plymouth Laboratory
}

In the course of phosphate determinations by the Denigès method it has been noticed that use of stannous chloride solutions containing some stannic tin and a low concentration of hydrochloric acid may give misleadingly high values for the reagent blank in distilled water, when the extinctions ${ }^{1}$ of the solutions are measured with a photoelectric absorptiometer in red light (Harvey, 1948). In daylight the solutions may show a perceptible yellow colour, or even, in extreme cases, a turbidity.

The magnitude of the effect has now been measured in reagent blank determinations with distilled water and in phosphate determinations with sea water. In sea water it is smaller or non-existent, so that the reagent blank value is inappropriate and causes over-correction of the measured phosphate content of the samples, leading to fictitiously low results.

The error may be from I to $2 \mathrm{mg}$. $/ \mathrm{m}^{3}$ of phosphate-phosphorus, or even higher when a turbidity is to be seen. It may be eliminated by ensuring that the stannous chloride solution contains about $5 \%$ by volume of concentrated hydrochloric acid.

The effect was first observed when an aged stock solution of stannous chloride was diluted with water to give a working solution which contained the required $0.3-0.45 \mathrm{mg}$. of stannous tin in three drops. When this was added to blank solutions these became faintly yellow in colour and the measured extinctions were greater than was expected. The stock solution had been prepared by dissolving $16 \mathrm{~g}$. of Analar stannous chloride in $40 \mathrm{ml}$. of a solution containing equal volumes of concentrated hydrochloric acid and water. It had undergone aerial oxidation in the course of II months, and a test showed that only $53 \%$ of its tin content was in the stannous form. It seemed likely that the presence of stannic tin in this solution had caused the high extinction values found, by producing a colloidal suspension of basic stannic compounds which absorbed or scattered light. Since the production of these compounds is known to be hindered in presence of hydrochloric acid, the experiment of diluting this aged stock solution with $5 \% \mathrm{v} / \mathrm{v}$ hydrochloric acid

1 The term 'extinction' is here used to denote the function $\log _{10} I_{0} / I$, where $I_{0}$ and $I$ are the intensities of the light entering and leaving the coloured solution. In the concentrations used, the molybdenum blue colour obeys the Beer-Lambert law so that extinction is proportional to the amount of blue compound present. All measurements were made in a $15 \mathrm{~cm}$. cell. 
instead of water was tried. (When diluted with water only, the resulting solution contains about $0.8 \%$ by volume of concentrated hydrochloric acid.) When the more acid solution was used for reagent blank determinations the extinction measured was found to be about one-third of that given by the stock solution diluted with water, and no yellow colour was apparent.

Other concentrations of hydrochloric acid were tried with the results shown in Table I. The reagent blank solution contained $67 \mathrm{ml}$. of distilled water and $3 \mathrm{ml}$. of a reagent containing $18 \%$ by volume concentrated sulphuric acid and $10.7 \%$ ammonium molybdate. The dilute stannous chloride solutions were adjusted so that each contained $0.45 \mathrm{mg}$. stannous tin in the 3 drops used. The best concentration appears to be $5 \%$ by volume.

Table I. Increase in Extinction (Measured in Red Light) of a Reagent BLANK Solution upon adDition of StanNous Chloride

$\begin{array}{ccc}\begin{array}{c}\text { Stock stannous chloride } \\ \text { diluted with }\end{array} & \begin{array}{c}\text { Increase in extinction } \\ \text { (in I5 cm. cell) }\end{array} & \begin{array}{c}\text { Calculated reagent blank } \\ \text { (mg. phosphate-P/m. }{ }^{3} \text { ) }\end{array} \\ \text { Water } & 0.024 & 2 \cdot 9 \\ & 0.024 & 2 \cdot 9 \\ \text { I } \% \mathrm{v} / \mathrm{v} \mathrm{HCl} & 0.020 & 2 \cdot 4 \\ & 0.022 & 2 \cdot 6 \\ 2 \% \mathrm{v} / \mathrm{v} \mathrm{HCl} & 0.010 & \mathrm{I} \cdot 2 \\ & 0.009 & \mathrm{I} \cdot \mathrm{I} \\ 5 \% \mathrm{v} / \mathrm{v} \mathrm{HCl} & 0.009 & \mathrm{I} \cdot \mathrm{I} \\ & 0.009 & \mathrm{I} \cdot \mathrm{I} \\ \mathrm{I} \% \mathrm{v} / \mathrm{v} \mathrm{HCl} & 0.0 \mathrm{I} 2 & \mathrm{I} \cdot 4 \\ & 0.0 \mathrm{I} 2 & \mathrm{I} \cdot 4\end{array}$

To see how the reagent blank was affected by varying stannic tin content of the stannous chloride solution, three solutions were made as follows:

(I) By dissolving $\mathrm{I} 6 \mathrm{~g}$. of $\mathrm{SnCl}_{2} \cdot 2 \mathrm{H}_{2} \mathrm{O}$ in $40 \mathrm{ml}$. of $\mathrm{I}: \mathrm{I} \mathrm{HCl}$, the salt being about ro years old and badly oxidized. The solution was found to contain $68 \%$ of stannous and $32 \%$ of stannic tin.

(2) By preparing a similar solution from fresh stannous chloride of good appearance. This contained $93 \%$ of stannous and $7 \%$ of stannic tin.

(3) By dissolving $8.4 \mathrm{~g}$. of tin in $32 \mathrm{ml}$. of conc. $\mathrm{HCl}$ and $8 \mathrm{ml}$. of water, adding two drops of $5 \%$ copper sulphate to assist solution. On test, this preparation was found to contain $100 \%$ stannous tin.

From each of these, diluted solutions of the same stannous tin content were made, in water and in $5 \% \mathrm{v} / \mathrm{v} \mathrm{HCl}$, and were used for reagent blank determinations. The results are shown in Table II.

From these it appears that in solutions diluted with water, high stannic tin content is accompanied by high reagent blank values. When hydrochloric acid is used the blanks appear to be independent of the stannic tin concentration. It is notable that even in the case of the reagent prepared by diluting the $100 \%$ stannous chloride with water there is an enhanced extinction, which may be due to the production of sufficient stannic tin in the diluted solution to cause some scattering of light. 
After this demonstration that the reagent blank is increased in distilled water if the stannous chloride reagent has a low $\mathrm{HCl}$ content and high stannic tin concentration, the effect in sea water was measured. The experiments were carried out under the same conditions as are used when phosphate in sea water

\section{Table II. Effect of Varying Stannic Tin Content of Stannous Chloride Reagent upon Reagent Blank}

\begin{tabular}{|c|c|c|c|c|c|}
\hline \multicolumn{2}{|c|}{$\begin{array}{l}\text { Fraction of total tin } \\
\text { content of stock solution in }\end{array}$} & \multicolumn{2}{|c|}{$\begin{array}{l}\text { Stock solution diluted } \\
\text { with water }\end{array}$} & \multicolumn{2}{|c|}{$\begin{array}{l}\text { Stock solution diluted with } \\
5 \% \mathrm{v} / \mathrm{v} \mathrm{HCl}\end{array}$} \\
\hline $\begin{array}{l}\text { Stannous } \\
\text { form }(\%)\end{array}$ & $\begin{array}{l}\text { Stannic } \\
\text { form }(\%)\end{array}$ & Extinction & $\underset{\left(\mathrm{mg} . / \mathrm{m} .^{3}\right)}{\text { Reagent blank }}$ & Extinction & $\underset{\left(\mathrm{mg} . / \mathrm{m} \cdot .^{3}\right)}{\text { Reagent blank }}$ \\
\hline 68 & 32 & $\begin{array}{l}0.023 \\
0.029\end{array}$ & $\begin{array}{l}2 \cdot 7 \\
3 \cdot 4\end{array}$ & $\begin{array}{l}0.009 \\
0.008\end{array}$ & $\begin{array}{l}\mathrm{I} \cdot \mathrm{I} \\
\mathrm{I} \cdot \mathrm{O}\end{array}$ \\
\hline 93 & 7 & $\begin{array}{l}0.024 \\
0.022\end{array}$ & $\begin{array}{l}2 \cdot 8 \\
2 \cdot 6\end{array}$ & $\begin{array}{l}0.007 \\
0.008\end{array}$ & $\begin{array}{l}0.8 \\
1 \cdot 0\end{array}$ \\
\hline 100 & Nil & $\begin{array}{l}0.018 \\
0.019\end{array}$ & $\begin{array}{l}2 \cdot I \\
2 \cdot 3\end{array}$ & $\begin{array}{l}0.009 \\
0.008\end{array}$ & $\begin{array}{l}I \cdot I \\
I \cdot O\end{array}$ \\
\hline
\end{tabular}

is determined, viz. to $67 \mathrm{ml}$. of sea water $3 \mathrm{ml}$. of a reagent containing I $8 \% \mathrm{v} / \mathrm{v} \mathrm{H}_{2} \mathrm{SO}_{4}$ and $10.7 \%$ ammonium molybdate were added. The extinction of the resulting solution was measured. Three drops of stannous chloride were added, and the extinction again measured when it had attained its maximum. To the solution $0.3 \mathrm{ml}$. of a standard phosphate solution was then added, increasing the phosphorus concentration by $20 \mathrm{mg}$. per $\mathrm{m}^{3}$, followed by a further two drops of stannous chloride. The extinction was measured again when it had reached its maximum. The difference between the first two readings was a measure of the phosphate-phosphorus content of the sea water, together with the blank contributed by the reagents. The difference between the second and third readings measured the extinction produced by unit quantity of phosphorus under the experimental conditions. A separate determination of the reagent blank allowed the phosphate-phosphorus content of the sea water to be calculated.

Table III shows results obtained with a sample of sea water of low phosphate content which had been filtered to remove any particulate matter which might contain phosphate (Cooper, I948, p. 298).

Although in absence of sufficient hydrochloric acid it is seen that the increase in extinction is enhanced by the presence of stannic tin, this enhancement is less in sea water than in distilled water; it has led in the extreme case to a negative value for the calculated phosphate-phosphorus. No significant alteration is seen in the extinction recorded after addition of phosphate subsequent to the first measurement.

The experiment was duplicated with the same sea water enriched with $8.9 \mathrm{mg} . / \mathrm{m}^{3}{ }^{3}$ of phosphate-phosphorus. The stannous chloride solutions in this experiment were different preparations. The results are shown in Table IV. 
The difference in extinction values for the addition of $20 \mathrm{mg} . / \mathrm{m} .^{3}$ phosphate-phosphorus between Tables III and IV can be accounted for by the temperature difference.

Table III. Estimation of Phosphate in Sea Water using Stannous Chloride Reagents Containing Equal Quantities of Stannous, and Varying Amounts of Stannic Tin. Temperature of Solutions, $22^{\circ} \mathrm{C}$.

\begin{tabular}{|c|c|c|c|c|}
\hline \multirow{4}{*}{$\begin{array}{l}\text { Stannic } \\
\text { tin content } \\
\text { of stock } \\
\text { solution as } \\
\text { fraction of } \\
\text { total tin } \\
\text { present }(\%)\end{array}$} & \multicolumn{4}{|c|}{ Stock solution diluted with water } \\
\hline & \multirow{2}{*}{\multicolumn{2}{|c|}{ Extinction in }} & \multirow{3}{*}{$\begin{array}{c}\text { Further increase in } \\
\text { extinction in sea } \\
\text { water after } \\
\text { subsequent addition } \\
\text { of } 20 \mathrm{mg} . / \mathrm{m}^{3} \\
\text { phosphate-P }\end{array}$} & \multirow{3}{*}{$\begin{array}{l}\text { Calculated } \\
\mathrm{PO}_{4}-\mathrm{P} \\
\left(\mathrm{mg} \cdot / \mathrm{m}^{3}\right)\end{array}$} \\
\hline & & & & \\
\hline & $\begin{array}{l}\text { Distilled } \\
\text { water }\end{array}$ & $\underset{\text { Sea }}{\text { water }}$ & & \\
\hline 67 & $0.068,0.069$ & $\begin{array}{l}0.037 \\
0.039\end{array}$ & $\begin{array}{l}0.168 \\
0.172\end{array}$ & $\begin{array}{l}-3 \cdot 8 \\
-3.4\end{array}$ \\
\hline 32 & $0.030,0.030$ & $\begin{array}{l}0.043 \\
0.040\end{array}$ & $\begin{array}{l}0.170 \\
0.172\end{array}$ & $\begin{array}{l}I \cdot 5 \\
I \cdot 2\end{array}$ \\
\hline Nil & o.or6, o.015 & $\begin{array}{l}0.031 \\
0.033\end{array}$ & $\begin{array}{l}0.167 \\
0.169\end{array}$ & $\begin{array}{l}I \cdot 9 \\
I \cdot 9\end{array}$ \\
\hline
\end{tabular}

\begin{tabular}{|c|c|c|c|}
\hline \multicolumn{2}{|c|}{ Extinction in } & \multirow{2}{*}{$\begin{array}{l}\text { Further increase in } \\
\text { extinction in sea } \\
\text { water after } \\
\text { subsequent addition } \\
\text { of } 20 \mathrm{mg} . / \mathrm{m} .^{3} \\
\text { phosphate-P }\end{array}$} & \multirow{2}{*}{$\begin{array}{l}\text { Calculated } \\
\mathrm{PO}_{4}-\mathrm{P} \\
\mathrm{mg} \cdot / \mathrm{m}^{3}\end{array}$} \\
\hline $\begin{array}{c}\text { Distilled } \\
\text { water }\end{array}$ & Sea & & \\
\hline $0.011,0.010$ & $\begin{array}{l}0.031 \\
0.033\end{array}$ & $\begin{array}{l}0.170 \\
0.168\end{array}$ & $\begin{array}{l}2 \cdot 4 \\
2 \cdot 6\end{array}$ \\
\hline $0.010,0.009$ & $\begin{array}{l}0.030 \\
0.030\end{array}$ & $\begin{array}{l}0.171 \\
0.169\end{array}$ & $\begin{array}{l}2 \cdot 4 \\
2 \cdot 4\end{array}$ \\
\hline o.010, o.010 & $\begin{array}{l}0.031 \\
0.033\end{array}$ & $\begin{array}{l}0.170 \\
0.168\end{array}$ & $\begin{array}{l}2.5 \\
2.6\end{array}$ \\
\hline
\end{tabular}

Table IV. Estimation of Phosphate in Sea Water Enriched with 8.9 MG. Phosphate-P per M. ${ }^{3}$ using Stannous Chloride Reagents Containing Equal Quantities of Stannous, and Varying Amounts of Stannic Tin. Temperature of Solutions, $20^{\circ} \mathrm{C}$.

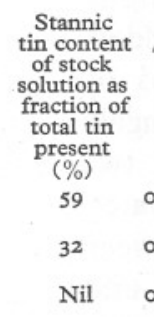

\begin{tabular}{|c|c|c|c|}
\hline \multicolumn{4}{|c|}{ Stock solution diluted with water } \\
\hline \multicolumn{2}{|c|}{ Extinction in } & \multirow{2}{*}{$\begin{array}{l}\text { Further increase in } \\
\text { extinction in sea } \\
\text { water after } \\
\text { subsequent addition } \\
\text { of } 20 \mathrm{mg} / \mathrm{m}^{3} \\
\text { phosphate-P }\end{array}$} & \multirow{2}{*}{$\begin{array}{c}\text { Calculated } \\
\mathrm{PO}_{4}-\mathrm{P} \\
\mathrm{mg} . / \mathrm{m}^{3}\end{array}$} \\
\hline $\begin{array}{l}\text { Distilled } \\
\text { water }\end{array}$ & $\begin{array}{c}\text { Sea } \\
\text { water }\end{array}$ & & \\
\hline $0.042,0.032$ & $\begin{array}{l}0.107 \\
0.108\end{array}$ & $\begin{array}{l}0.166 \\
0.167\end{array}$ & $\begin{array}{l}8 \cdot 4 \\
8 \cdot 5\end{array}$ \\
\hline $0.030,0.030$ & $\begin{array}{l}\text { O.III } \\
0.116\end{array}$ & $\begin{array}{l}0.167 \\
0.168\end{array}$ & $\begin{array}{r}9 \cdot 7 \\
10 \cdot 2\end{array}$ \\
\hline o.or4, o.013 & $\begin{array}{l}0.108 \\
0.107\end{array}$ & $\begin{array}{l}0.167 \\
0.167\end{array}$ & $\begin{array}{l}\text { II } \cdot 2 \\
I I \cdot I\end{array}$ \\
\hline
\end{tabular}

\begin{tabular}{|c|c|c|c|}
\hline \multicolumn{4}{|c|}{ Stock solution diluted with $5 \% \mathrm{v} / \mathrm{v} \cdot \mathrm{HCl}$} \\
\hline \multicolumn{2}{|c|}{ Extinction in } & \multirow{2}{*}{$\begin{array}{l}\text { Further increase in } \\
\text { extinction in sea } \\
\text { water after } \\
\text { subsequent addition } \\
\text { of } 20 \mathrm{mg} . / \mathrm{m}^{3} \\
\text { phosphate-P }\end{array}$} & \multirow{2}{*}{$\begin{array}{c}\text { Calculated } \\
\mathrm{PO}_{4}-\mathrm{P} \\
\mathrm{mg} \cdot / \mathrm{m}^{3}\end{array}$} \\
\hline $\begin{array}{l}\text { Distilled } \\
\text { water }\end{array}$ & $\begin{array}{c}\text { Sea } \\
\text { water }\end{array}$ & & \\
\hline $0.010,0.010$ & $\begin{array}{l}0.107 \\
0.107\end{array}$ & $\begin{array}{l}0.167 \\
0.168\end{array}$ & $\begin{array}{l}\text { II.6 } \\
\text { II. } 6\end{array}$ \\
\hline $0.011,0.011$ & $\begin{array}{l}0.109 \\
0.109\end{array}$ & $\begin{array}{l}0.167 \\
0.168\end{array}$ & $\begin{array}{l}\text { II } \cdot 7 \\
\text { II } 7\end{array}$ \\
\hline $0.009,0.009$ & $\begin{array}{l}0.107 \\
0.107\end{array}$ & $\begin{array}{l}0.168 \\
0.168\end{array}$ & $\begin{array}{l}\text { II } 7 \\
\text { II } 7\end{array}$ \\
\hline
\end{tabular}

The last columns of these tables, showing the calculated phosphorus in the sea water without and with the addition of $8.9 \mathrm{mg}$. $/ \mathrm{m} .{ }^{3}$, show a mean difference of $9.18 \mathrm{mg} . / \mathrm{m} .{ }^{3}$ with a maximum difference of 9.3 and a minimum difference of $9 \cdot 0$. This estimated difference is considered to be in reasonable agreement with the known addition of phosphate, and indicates that the technique of 'subsequent addition' is valid (Harvey, 1948, p. 351).

It is therefore recommended that the stannous chloride used in this method should contain at least $5 \%$ by volume of concentrated hydrochloric acid.

This condition, it should be noted, is complied with in the original visual method of Atkins (1923, p. I44), in which the freshly prepared stannous chloride contains Io to $20 \%$ by volume of acid. In any event the presence of stannic tin with a low acid concentration is less likely to upset the visual estimation of the reagent blank, as its effect is to discolour, not augment, any blue colour formed. 


\section{SUMMARY}

The results of phosphate determinations in sea water by the Denigès method, using red light, in an absorptiometer, may be in error if the stannous chloride reagent has low $\mathrm{HCl}$ concentration, and contains stannic tin.

The error is in the reagent blank determination, and seems to be caused by colloidal stannic compounds which increase the opacity of the solution. In sea water the effect may be smaller or immeasurable so that results are over-corrected.

When the stannous chloride solution contains about $5 \%$ hydrochloric acid, reagent blank figures are low, and independent of stannic tin concentration. This acidity is recommended.

\section{REFERENCES}

AtKINS, W. R. G., I923. The phosphate content of fresh and salt waters in its relationship to the growth of the algal plankton. Fourn. Mar. Biol. Assoc., Vol. xIII, pp. II9-50.

COOPER, L. H. N., I948. The distribution of iron in the waters of the western English Channel. Fourn. Mar. Biol. Assoc., Vol. xxviI, pp. 279-3I3.

HARVEY, H. W., I948. The estimation of phosphate and of total phosphorus in sea waters. Fourn. Mar. Biol. Assoc., Vol. xxvII, pp. 337-59. 